\title{
BUSINESS ANALYSIS OF AMONIATION AND FERMENTATION PALM OIL FRONDS AS A SUBSTITUTION OF FORAGE ON ACEH CATTLE IN KECAMATAN SELESAI
}

\author{
H F Ginting, E Mirwandhon, T H Wahyuni, M Tafsin, N Ginting \\ Animal Production Program, Faculty of Agriculture, Universitas Sumatera Utara, \\ Medan 20155 \\ E-mail: nurzainahginting@gmail.com
}

\begin{abstract}
The experiment was conducted in Kecamatan Selesai from June to August 2016. The method used was survey method with consideration of the aceh cattle studies using palm oil fronds in amoniation and fermentation as a substitution of forage in Kecamatan Selesai, with the division of business scale. Criteria for determining the scale of business was based on the number of livestock ownership. Determination limit frequency distribution length of the class, was the ownership of the largest ownership reduced smallest in the length of class. The result showed that every treatments $\mathrm{P} 0, \mathrm{P} 1, \mathrm{P} 2, \mathrm{P} 3$ provide different results to average of total cost production (Rp/ekor/peroide): P0 6.284.187,69, P1 Rp. 6.502.768,02, P2 Rp. 6.225.270,04, and P3 Rp. 6.459.359. The average of total cost production (Rp/ekor/periode): P0 Rp. 6.430.300,00, P1 Rp. 6.688.470,00, P2 Rp. 6.666.010,00,- and P3 Rp. 6.666.010. The average of analysis profit/loss(Rp/ekor/periode): P0 Rp. 146.112,31; P1 Rp. 185.701,98, ; P2 Rp.440.739,96 dan P3 Rp.190.940,20. The average of R/C ratio: 1,02; 1,03; 1,07 dan 1,03. The Average of IOFC (Rp/ekor/periode): 197.687,31; 240.356,98; 490.354,96 and 242.515,20. The results of this research was utilization of palm oil fronds which treated phisical + fermentation can increase income of cattle raiser.
\end{abstract}

\section{Introduction}

The advancement and development of science in the field of livestock alter the mindset to utilize the agricultural and plantation waste byproducts which will feed alternative livestock of high quality and economical. One of them is palm oil waste which is a plantation waste that is usually only left or disposed of.

Judging from the content of feed substances contained in it, palm oil waste has the potential to be used as ruminants feed ingredients.

The use of palm oil waste as one of the feeds that can be used is also supported by areas in Indonesia which are mostly oil palm plantations. Palm oil is a rapidly growing plant in Southeast Asia including Indonesia. Directorate General of Plantation (2011) stated that the area of oil palm plantations in Indonesia reaches $8,910,000 \mathrm{Ha}$ with details of the area of large private plantation $4.650 .000 \mathrm{Ha}$, the area of 3.620.000 Ha of Public Plantation and the area of Plantation of 640,000 Ha. While in the 
region of North Sumatra the growth rate of oil palm plantation production is very significant in yielding oil palm by-product. In 2011, the area of plantation increased to 1,175,078 $\mathrm{Ha}$.

Analysis of livestock business is a very important activity for a commercial livestock business. By conducting this business analysis activities can be searched steps to solve various obstacles to be faced. Analysis of livestock business also aims to find points and benchmarks to improve the constraints faced. The results of this analysis can be used to plan the expansion of business either add branch business or can estimate the cost to be developed to advance the livestock business. And based on these data can be measured business profits and the availability of real funds for the next period.

Based on the description, the authors are interested in conducting research entitled "Analysis of Utilization of Palm Oil Absorption Processed in Ammonia and Fermentation in Cow Aceh".

\section{Materials and Methods}

\subsection{Place and time of research}

The research was conducted in Tanjung Merahe Village, Padang Blarang, Kecamatan Done. The study lasted for 3 months, starting from June to June of 2016.

\subsection{Types and Data Sources}

The research method used is survey method with consideration of the maintenance of local aceh cattle with the use of palm oil stem rations that are processed ecara amoniasi and fermentation as grass feed grass with community farms in the finished districts, which is one of the areas of oil palm plantations. Secondary data taken through the various literature used as reference material to support the primary data during the research process. Secondary data used by daritext book, scientific journal, research report (thesis), internet site, and data obtained through related institutions such as Central Bureau of Statistics (BPS) and Agriculture Office of Medan City of North Sumatra.

\subsection{Method of collecting data}

This research was conducted by using primary data which was done by observation and interview by using questionnaire. The questionnaire contains open and closed questions (structured). Open questions include questions whose answers are descriptions or are not provided while closed questions contain questions whose answers have been provided. The questionnaire is addressed to the respondents and marketing agencies involved during the marketing process. Determination of marketing agency respondents conducted by snowball sampling method. This method is derived from the information obtained after interviews with previous respondents regarding marketing channels of beef cattle in the animal market. This method is done with the aim to trace the flow of products and the involvement of marketing institutions in performing its marketing functions.

\subsection{Method of Processing and Data Analysis}

Analyzed the data that has been collected to find out which data we need and can be an information for the research.

The analysis is as follows:

1. Analyze the data from the results of aceh cow study using palm oil heap that is processed by amoniation and fermentation.

2. Analyzing data from the survey results at the community farms in the kecamatan completed with the division of business scale. According Wulandari (2014) that the criteria of determining the scale of business is based on the number of livestock ownership cultivated. Determination of the limit of the class length frequency distribution, that the determination of the range ie the largest ownership minus the smallest ownership divided by the length of the class. The division of business scale is based on the formula:

Interval $=($ largest ownership - smallest ownership $) / 3$

Interval $=25-2=7$ heads 
3

1. Scale $\mathrm{I}=2+7=9 \mathrm{kor}$

2 to 9 tails

2. Scale II $=10+7=17 \mathrm{kor}$

10something with $17 \mathrm{kor}$

3. Scale III $=18+7=25 \mathrm{kor}$

18 to 25 tailsassumes the use of fermented acetylated sterile palm leaves.

1. Assume the use of palm-oil-treated sheaves.

in general, performs an exchange function (sales and purchases), physical functions (packaging, transportation, and storage) and facility functions (financing, risk coverage, market information and standardization).

\section{Results and discussion}

\subsection{Total Production Cost}

In Table 2 it can be seen that the production cost of the use of midrib during one study period shows the difference that where the average production cost of cattle raising using oil palm bleeding during the highest research was found on amber palm oil processed as much as Rp.26.096.813 / period.

This occurs because the ammoniation treatment of seed costs is greater than other treatments. Assuming the cost of seedlings is the same, the highest total production cost is the palm oil heap that is processed by Ammoniation + fermentation. This occurs because the cost of fermentation + amoniation rations is Rp.396.679, - greater than other treatments while other production costs such as seeds, drug costs, cage making, cage equipment, labor, and electricity and water costs are the same. This is as expressed by Budiono (1990), that cost is the value of all necessary economic burdens that are unavoidable, predictable and measurable to produce a product [1].

Dairy farmers in the sub-district have finished cattle between 2 to 25 heads and are divided into 3 scales: Scale I, scale II, and scale III. Table 3 shows that the highest total production cost is on the third scale of Rp.204.504.000 / period compared to the first and second scales of Rp.40.342.727 / period and Rp.84.116.000 / period. This is because the number of livestock owned on Scale III more than Scale I and II so that the total production costs incurred is also greater.

If the cattle ranchers in Kecamatan Selesai are assumed to use only grass or grazed feed then on a scale I the total production cost to be incurred each period is Rp.40.342.727 / period, while the scale II and the third scale is Rp.84.116.000 / periodedanRp. 204,504,000 / period.

\subsection{Total Production Results}

In Table 2 it can be seen that the total yield of cow breeding production during one month is highest is in the treatment of oil palm treated coconut oil that amounted to Rp.26.570.200. This happens because there is a price difference in the price of seeds so that the value of income from sales of larger cows. This is in accordance with the statement of Sudarmono and Sugeng (2003), which states that business income is all revenues earned in a business [2]. Revenues can be in the form of main income, such as the proceeds from the sale of cattle and incomes, such as manure as well as a statement from kadarsan (1995), which states that the company's revenues are sourced from the marketing or selling of business proceeds such as crops and their processed products and harvests from livestock processed products.

The total production result from the survey conducted at the farm in the sub-district is completed can be seen in Table 3, showing that it has a difference on each Scale, with the highest total production on scale III that is Rp.265.642.000 / period, while on Scale I and II amounting to Rp.50,981,818 / period and Rp.130.110.000 / period. The difference in total yields on each scale is due to the amount of livestock raising and production produced, and the amount of income does not guarantee the size of a business. this is in line with Ucokaren's (2011) statement, which states that large farm revenues and profits do not necessarily reflect high levels of business efficiency [3]. 
Figure 2 shows that total production yields assuming the use of fermented palm oil briquettes is higher than that of grass or pasture feed. On the third scale is the total difference of the highest yield of Rp. $51,936,400$ / period while the scale I is Rp.13,783,855 / period, increase the total production of each scale. It is hoped that the assumption of the use of palm oil that is processed in fermentation process is more efficient to be used because it can produce more profit per period in the people farmer in Kecamatan of Selesai.

\subsection{Profit and loss}

Profit / Loss Analysis is to find out whether the business loss or profit by calculating the difference between total revenue or total production and total expenditure or total production costs.

In Table 2 it can be seen that the profit / loss analysis if it is assumed to use fermentation stem during one month of maintenance shows a large difference at each level where the highest profit is found in fermented palm oil processed bulk of Rp.900.990, - and which provides benefits the lowest on the palm oil heap that is physically processed is Rp.254.893, - whereas in the processed fermentation + amoniasi processed leaves provide a good profit of Rp.672.700.

The highest gain is in the fermented processed bark, this is because the increase in body weight of the cow per day is higher than the other treatments. So the total production of the total sales of feces and the sale of cattle has a higher value than the total cost of production, namely the cost of purchasing seeds, ration costs, the cost of medicines, the cost of making the cage, the cost of cage equipment, labor costs, transportation costs and costs electricity and water. This is in accordance with the interpretation of Murtidjo (1995), ie profit is the goal of every business [4]. Profit can be achieved if the amount of income earned from the business is greater than the amount of expenditure. When the profits of a business increase, then the business is economically feasible to be maintained or enhanced. To obtain a definite number of profits or losses, what should be done is the recording of costs. The purpose of recording costs also for farmers or entrepreneurs to conduct an evaluation of the business field.

Based on Table 3 the results of profit / loss analysis performed on cattle ranchers in District Finish there is a difference in profit / loss on each scale. The largest profit / loss is on the third scale of Rp.61.138.000, - / period while the lowest on the scale I is Rp.10.639.091, - / period, and the second scale of Rp.45.994.000, - / period. This difference is due to the average number of livestock owned by each Scale so that scale III is more profitable.

\section{4. $R$ / C Ratio}

The R / C Ratio Analysis is used in an attempt to find out whether or not the effort is to be continued into the next period or otherwise the business is terminated because it is less feasible.

$\mathrm{R} / \mathrm{C}$ Ratio is obtained by distributing total production with total production cost or written with formula:

$\mathrm{R} / \mathrm{C}$ Ratio $=($ Total Production Result $) /($ Total Production Cost $)$

In Table 2 it can be seen that the R / C Ratio obtained shows that the processed physical betel feed is still considered to have eligibility to continue but not to be applied. Since it has a R / C Ratio of 1.01 ( $\mathrm{R} / \mathrm{C}>1$ ), the midrib treated ammonia is considered feasible but not diluted to continue because it has a mean of 1.02 ie ( $\mathrm{R} / \mathrm{C}>1)$, amber processed ammonium fermented feed + fermentation is considered feasible to continue because it has a mean of 1.03 ie $(\mathrm{R} / \mathrm{C}>1)$ and fermented processed sterilized feed is also very feasible to continue because it has a mean of $1.04(\mathrm{R} / \mathrm{C}>1)$. This is in accordance with the statement Kadariah (1987), states that to determine the efficiency level of a business can be used parameters that is by measuring the amount of income divided by the amount of expenditure, where:

- $\mathrm{R} / \mathrm{C}$ ratio> 1 , livestock business worth developing

$-\mathrm{R} / \mathrm{C}$ ratio $=1$, livestock business is not profitable and no loss (breakeven).

$-\mathrm{R} / \mathrm{C}$ ratio $<1$, livestock business is not feasible to develop 
The highest $\mathrm{R} / \mathrm{C}$ ratio was found in the processed fermented calf feed of 1.04 and the lowest $\mathrm{R} / \mathrm{C}$ value Ratio was obtained on physically processed feed of 1.01. This is in accordance with the statement of Karo-Karo et al. (1995), that business can be said to give an advantage when the value of R / C Ratio> 1 [5].

\subsection{IOFC}

Income Over Feed Cost (IOFC) is the difference between total livestock business income and reduced feed costs. This Income Over Feed Cost (IOFC) is a barometer to see the large cost of feed which is the biggest cost in the livestock raising business.

In Table 2 it can be seen that the highest IOFC when using fermented palm oil processed palm oil is Rp.1.422.270 and the lowest is in physically processed stem-feed that is Rp.775.613. whereas in the treated banana with amoniation and ammonite + fermentation amounted to Rp.948.558 and Rp.1.198.320.

This is in line with Prawirokusumo's (1990) statement, which states that the Income Over Feed Cost (IOFC) is the difference in total revenue with the feed costs used during the livestock raising business. In Table 3 it can be seen that the IOFC value of the people farmers in Kecamatan Dish is different on each Scale. The highest IOFC value on Scale III is Rp.285.600.000 and the lowest on scale I is Rp.48.732.727 and the second scale is Rp.124.384.000. the difference in IOFC value can be affected by the amount of feed used and the number of livestock kept so that it will affect the cost of feed and income.

\section{Conclusions}

1. Result of profit / loss calculation from result of research that cow breeding business using palm oil processed palm oil is more advantageous when compared with processing of palm oil midboard physically, amoniasi, or amoniasi + fermentation

2. Survey results on smallholder farms in KecamatanSelesai, the most efficient scale of the farmers' ownership is the scale III when compared to the scale I and II

3. If the people's farmers in Kecamatan Districts are assumed to use fermented oil palm-stemmed fodder is more feasible than using only grass so it can increase the income of farmers

\section{References :}

[1] Budiono, 1990. Ekonomi Mikro. Seri Sinopsis Pengantar Ilmu Ekonomi No. 1. Edisi kedua, Cetakan ke II. BPFE, Yogyakarta

[2] Sudarmono, A.S dan Y. Bambang. S. 2008. Sapi Potong Pemeliharaan, Perbaikan, Produksi, Prospek Bisnis, Analisis Penggemukan. BPFE, Jakarta

[3] Ucokaren. 2011. Analisis Ilmu Uata Usahatani. http://sayangpetani.wordpress.com/2011/06/16/analisis-data-ilmu-usahatani/

[4] Murtidjo,B. A., 1995. Analisa Usaha Beternak Sapi potong Intensif, .Penebar Swadaya. Jakarta

[5] Karo - Karo, S., Junias Sirait and Henk Knipsheer.1995. Farmers Shares, Marketing Margin and Demand for Small Ruminant In North Sumatera, Working Paper No.150 November. 